\title{
Evaluation of enzymatic activity and identification of potent proteolytic and chitinolytic bacteria isolated from crab shell waste
}

\author{
MOH DLIYAUDDIN ${ }^{1,2, \vartheta}$, TRI ARDYATI $^{1}$, SUHARJONO $^{1}$ \\ ${ }^{1}$ Department of Biology, Faculty of Mathematics and Natural Sciences, Universitas Brawijaya. J1. Veteran No.1, Malang 65145, East Java, Indonesia. \\ Tel.: +62-341-575841, `email: m.dliyauddin.md@ gmail.com. \\ ${ }^{2}$ Biology Graduate Program, Department of Biology, Faculty of Mathematics and Natural Sciences, Universitas Brawijaya. Jl. Veteran No.1, Malang \\ 65145, East Java, Indonesia
}

Manuscript received: 22 October 2019. Revision accepted: 22 December 2019

\begin{abstract}
Dliyauddin M, Ardyati T, Suharjono. 2020. Evaluation of enzymatic activity and Identification of Potent Proteolytic and Chitinolytic Bacteria Isolated from Crab Shell Waste. Biodiversitas 21: 211-218. Proteolytic and chitinolytic bacteria are needed to degrade protein-chitin fibers in crab shell waste. These bacteria are important for enhancing the degradation rate of crab shell waste in the environment. This study aims to study the enzymatic activity and identify potent proteolytic and chitinolytic bacteria based on $16 \mathrm{~S}$ rDNA sequences. The bacteria were isolated from crab shell waste using skim milk agar and colloidal chitin agar for proteolytic and chitinolytic bacteria, respectively. The bacterial isolates were screened based on their protease and chitinase activity using casein and chitin as substrates, respectively. The selected isolates were identified based on 16S rDNA sequences similarity. A total of 20 proteolytic and 22 chitinolytic bacteria were successfully isolated from the samples. The isolate of AP9, AP5, and BP14 had a high protease activity. However, only BP14 and CK20 showed a high chitinase activity. The isolate of AP9 was identified as Bacillus subtilis, AP5, and CK20 were identified as Bacillus licheniformis, and BP14 was identified as Bacillus cereus. AP5 dan CK20 were classified as non-pathogenic isolates.
\end{abstract}

Keywords: Bacillus cereus, Bacillus licheniformis, Bacillus subtilis, chitinolytic bacteria, proteolytic bacteria

\section{INTRODUCTION}

Crab is one of the important crustaceans food in Indonesia. Crab, especially the Portunus pelagicus, is Indonesia's main export commodity. However, only crab meat is used as an export commodity while crab shells are converted as feed, fertilizers, or it discarded and polluted the environment (Ordónez-Del Pazo et al. 2014). Crab exports have important value that contributes to the foreign exchange for Indonesia's economic growth. Demand for crab is increasing every year in the global market.

As a consequence, Indonesia's crab export volume in 2010 amounted to 21,537 tons and expanded in 2013 to around 34.17 tons per year (Riniwati et al. 2017). It can cause an increase in crab shell waste, which can lead to environmental problems. In Indonesia, crab shell waste is usually processed to produce animal feed. Recently, many studies have discovered the potential of fish and crustacean processing byproducts into valuable bio-compounds such as collagen and gelatin (Rustad et al. 2011), bioactive peptides (Sanmartin et al. 2012), specific enzymes and proteins (Magesawari et al. 2017), chitin, chitosan, and astaxanthin pigments (Nouri et al. 2016) that are beneficial to the environment. On the other hand, various studies have been carried out on the application of protease and chitinase enzymes in the process of deproteinization and demineralization of crustacean shells which are considered capable of overcoming environmental problems originating from fishery wastes into valuable byproducts (Lopes et al. 2017) such as protein (20-40\%) (Senphan et al. 2014) and chitin (20-30\% on dry weight basis) (Hajji et al. 2014).

Chitin is the main structural compounds of crab shells in the cuticle layer, produces a derivative product in the form of chitosan (ß-(1-4)-poly-N-acetyl-D-glucosamine) from the enzymatic or chemical deacetylation process, and the second most abundance polysaccharide after cellulose (Elieh-Ali-Komi and Hamblin 2016). Chitin and chitosan are bio-compounds with high economic value and attractive for industrial use (food industry, pharmaceuticals, cosmetics, textile, chemical industry, etc.) (Lopes et al. 2017). However, chitin in crab shell waste is closely associated with proteins, minerals, lipids, and pigments that have to be removed (Gadgey and Bahekar 2017). Conventionally, chitin is extracted by chemical treatment for demineralization and deproteinization, with the use of strong acids and bases (Tolaimate et al. 2003). However, the use of these chemicals can cause partial deacetylation and depolymerization of chitin (Kumari 2012), which affects the physiological and structural properties of the final product (Gortari and Hours 2013) and causes limited applications. Therefore, the use of bacteria that produce protease and chitinase enzymes for deproteinization and demineralization of a crab shell is a safe and environmentally friendly alternative to degrade chitin into chitosan (Elieh-Ali-Komi and Hamblin 2016).

Chitin and chitosan are widely used for biomedical applications due to their characteristics such as biocompatibility, biodegradability, non-toxicity, and possess antimicrobial and hydration properties (Jayakumar et al. 2011). In biomedical applications, chitin is usually 
converted into chitosan and used for tissue engineering, drug, and gene delivery, wound dressings, wound healing, and stem cell technology (Azuma et al. 2014). Abundant crab shell waste in Indonesia can be used to produce chitosan, which has economic benefits and reduces the impact of environmental pollution. Exploration of indigenous proteolytic and chitinolytic bacteria from crab shell waste is an important initial step to obtain bacterial strains that can utilize chitin-protein fibers of the crab exoskeleton. Therefore, this study aims to evaluate the enzyme activity and identify bacterial strains isolated from crab shell waste with potent protease and chitinase activity based on $16 \mathrm{~S}$ rDNA sequences.

\section{MATERIALS AND METHODS}

\section{Proteolytic and Chitinolytic Bacterial Isolation}

Crab shells waste was collected from three different locations of crab home industry in Pati Regency and two locations in Rembang Regency, Central Java Province, Indonesia. Crab shells were ground using sterile mortar and pestle. Organic matter and $\mathrm{C}$-organic content, moisture content, $\mathrm{pH}$, and temperature of the samples were measured. A total of $25 \mathrm{~g}$ sample was diluted serially with physiological saline up to $10^{-6}$ dilutions, then $0.1 \mathrm{~mL}$ suspension from each dilution was inoculated on skim milk agar medium (casein $0.5 \%$, yeast extract $0.25 \%$, dextrose $0.1 \%$, skim milk $2.8 \%$, and $1.5 \%$ Bacto agar) in a petri dish to isolate proteolytic bacteria (Tennalli et al. 2012) and incubated at $37{ }^{\circ} \mathrm{C}$ for $24 \mathrm{~h}$. Colloidal chitin agar (CCA) (chitin $0,5 \%$, yeast extract $0,5 \%$, bacto agar $1.5 \%$, $\mathrm{Na}_{2} \mathrm{HPO}_{4} 0,6 \%, \mathrm{KH}_{2} \mathrm{PO}_{4} 0,3 \%, \mathrm{NH}_{4} \mathrm{Cl} 0,6 \%$ and $\mathrm{NaCl}$ $0,1 \%$ ) with modifications was used to isolate chitinolytic bacteria (Saima et al. 2013) and incubated at $30{ }^{\circ} \mathrm{C}$ for 48 h. The clear zone was measured, and bacterial colonies were counted based on the total plate count method to determine the bacterial density of the samples. Bacteria were sub-cultured to obtain single and pure colony. Colloidal chitin was prepared from crab shells as follows: a total of $25 \mathrm{~g}$ dried crab shell was diluted in $250 \mathrm{~mL}$ of $37 \%$ Hydrochloric acid and shaken at $700 \mathrm{rpm}$ for $2 \mathrm{~h}$ at $30^{\circ} \mathrm{C}$, or until the chitin was dissolved and became colloid. This colloid was diluted to $1000 \mathrm{~mL}$ of absolute cold ethanol and shaken at $1000 \mathrm{rpm}$ at $30^{\circ} \mathrm{C}$ until dissolved. The $\mathrm{pH}$ of mixture was adjusted to 7 and centrifuged at $8000 \mathrm{rpm}$ for 10 minutes at $30^{\circ} \mathrm{C}$. The pellet was dried to form chitin powder (Faramarzi et al. 2009).

\section{Enzymatic activity assays}

\section{Protease activity}

The proteolytic bacterial isolates were assayed for its protease enzyme activity according to the completely randomized design. The protease enzyme activity was measured using L-tyrosine standard curve. Enzymatic activities (protease and chitinase) of bacterial isolated were assayed to select bacterial strains with the best proteolytic and chitinolytic activity. For protease activity assay was performed as follows: one loop of bacterial isolate was grown in skim milk broth medium $\left(5 \mathrm{~g} \mathrm{~L}^{-1}\right.$ casein, $2.5 \mathrm{~g} \mathrm{~L}^{-1}$ yeast extract, $1 \mathrm{~g} \mathrm{~L}^{-1}$ glucose, $1 \mathrm{~g} \mathrm{~L}^{-1}$ skim milk) (Fulzele et al. 2011), and incubated at $37^{\circ} \mathrm{C}$ for $24 \mathrm{~h}$. Bacterial culture $(10 \%)$ was inoculated into skimmed milk broth medium and incubated at $37^{\circ} \mathrm{C}$ for $24 \mathrm{~h}$ for enzyme production. The density of the cell of each bacterial isolates was measured in terms of optical density OD) at $600 \mathrm{~nm}$ (Raut et al. 2012). The growth media dan biomass was centrifuged at $10000 \mathrm{rpm} ; 10 \mathrm{~min}$, at $4{ }^{\circ} \mathrm{C}$ to obtain the cell freesupernatant (CFS) as the extracellular enzyme substances. Protease activity was assayed based on the Standard method of Sigma (Cupp-Enyard 2008) with modification. One unit of protease enzyme was defined as the number of enzymes that hydrolyzes casein to produce $1 \mu$ mole of tyrosine per minute. CFS was reacted to $1 \%$ casein as a substrate and incubated at $37^{\circ} \mathrm{C}$ for $20 \mathrm{~min}$. The reaction was stopped by adding $110 \mathrm{mM}$ Trichloroacetic acid (TCA) solution. The absorbance of the solution was measured using UV-Vis spectrophotometry (Thermo Spectronic, New York, USA) at $540 \mathrm{~nm}$ wavelength.

\section{Chitinase activity}

The chitinolytic bacterial isolates were assayed for its chitinase enzyme activity according to the completely randomized design. Bacterial isolates were grown in colloidal chitin broth (CCB) medium containing $0.5 \%$ colloidal chitin, $0.5 \%$ yeast extract, $0.6 \% \mathrm{Na}_{2} \mathrm{HPO}_{4}, 0.1 \%$ $\mathrm{NaCl}, 0.6 \% \mathrm{NH}_{4} \mathrm{Cl}$, and $0.3 \% \mathrm{KH}_{2} \mathrm{PO}_{4}$ and incubated at $30^{\circ} \mathrm{C}$ fo $48 \mathrm{~h}$. Bacterial culture suspension $(10 \%)$ was inoculated into CCB medium and incubated at $30{ }^{\circ} \mathrm{C}$ for 48 h. Bacterial cell density was adjusted to equal; then it centrifuged at $10000 \mathrm{rpm}$ for $10 \mathrm{~min}$ at $4{ }^{\circ} \mathrm{C}$ to obtain the CFS that contain chitinase enzyme. Chitinase enzyme activity was assayed using $750 \mu \mathrm{L}$ of $1 \%$ colloidal chitin and $750 \mu \mathrm{L}$ of enzyme solution and incubated at $30{ }^{\circ} \mathrm{C}$ for $2 \mathrm{~h}$. The suspension was added with $500 \mu \mathrm{L}$ of 3,5dinitrosalicylic acid reagent and heated at $100^{\circ} \mathrm{C}$ for $5 \mathrm{~min}$. The absorbance of the solution was measured at $540 \mathrm{~nm}$ wavelength (Zarei et al. 2011). One unit of chitinase enzyme activity was defined as the number of enzymes that hydrolyzes chitin to release $1 \mu \mathrm{g}$ of N-acetyl-Dglucosamine per hour. The bacterial strains with the highest enzymatic activities in both of the protease and chitinase were identified based on $16 \mathrm{~S}$ rDNA sequence similarity.

\section{Hemolytic activity assays}

Hemolysis activity assays on selected proteolytic and chitinolytic bacteria were carried out to determine the pathogenic and non-pathogenic properties of selected bacterial isolates. Bacterial isolates were grown on the blood agar media and incubated at $30^{\circ} \mathrm{C}$ for 24 hours (Angmo et al. 2016). Bacterial isolates without clear zone (gamma hemolytic or non-hemolytic) indicated as nonpathogenic bacteria, while bacterial isolates with the clear zone ( $\beta$-hemolytic or complete hemolytic) or halo greenish ( $\alpha$-hemolytic or partial hemolytic) are pathogenic bacteria. 


\section{Bacterial identification based on 16S rDNA sequences similarity}

The selected isolates with the highest protease and chitinase activity were cultured on nutrient agar medium and incubated at $30{ }^{\circ} \mathrm{C}$ for $24 \mathrm{~h}$. The chromosomal DNA of selected isolates was extracted based on the standard protocol of Quick-DNATM Fungal/Bacterial Miniprep Kit (Zymo research corp., Tustin, USA). The 16S rDNA of bacteria was amplified using universal primers of $27 \mathrm{f}\left(5^{\prime}\right.$ AGA GTT TGA TCC TGG CTC AG-3') and 1492r (5'GGT TAC CTT CTT ACG ACT T-3'). The PCR mixture was contained $25 \mu \mathrm{L}$ of GoTaq ${ }^{\circledR G}$ Green Master Mix $(2 \mathrm{x})$ (Promega, Wisconsin, USA), $2 \mu \mathrm{L}$ of each forward and reverse primers, $2 \mu \mathrm{L}$ of DNA templates, and $19 \mu \mathrm{L}$ of nuclease-free water (Mulyawati et al. 2019). The PCR reaction was started with an initial denaturation at $94{ }^{\circ} \mathrm{C}$ for 5 min continued with 35 cycles of denaturation $\left(94{ }^{\circ} \mathrm{C}\right.$; $30 \mathrm{~s})$, annealing $\left(55^{\circ} \mathrm{C} ; 60 \mathrm{~s}\right)$, and elongation $\left(72^{\circ} \mathrm{C} ; 90 \mathrm{~s}\right)$ and final elongation at $72{ }^{\circ} \mathrm{C}$ for $5 \mathrm{~min}$. The amplicon of $16 \mathrm{~S}$ rDNA was confirmed using $1.5 \%$ agarose gel electrophoresis using TBE buffer $1 \mathrm{x}$ and $1 \mu \mathrm{L}$ of EtBr. The electrophoresis was carried out for $30 \mathrm{~min}$ with $100 \mathrm{~V}$, and the bands were visualized using UV Transilluminator (Vilber Lourmat, Deutschland, Germany). The 16S rDNA was sequenced at 1st BASE DNA Sequencing Service, Malaysia. The sequences of $16 \mathrm{~S}$ rDNA alignment with sequences references in NCBI database. The phylogenetic tree was constructed using MEGA 6 software for Windows-based on the Neighbor-Joining algorithm and the Tamura-Nei model.

\section{Statistical analysis}

Data of enzymatic activities were analyzed by Analysis of Variance (ANOVA) using SPSS 16.0 software for windows. The significant differences were determined based on the Tukey's analysis with $\mathrm{p}<0.05$.

\section{RESULTS AND DISCUSSION}

\section{Proteolytic and chitinolytic bacteria}

The population density of proteolytic bacteria was relatively lower than the population density of chitinolytic bacteria. The density of chitinolytic bacteria at locations A, $\mathrm{B}$, and $\mathrm{C}$ were $4.96 \times 10^{4} \mathrm{CFU} \mathrm{g}^{-1}, 11.13 \times 10^{4} \mathrm{CFU} \mathrm{g}^{-1}$, and $4.63 \times 10^{4} \mathrm{CFU} \mathrm{g}^{-1}$ respectively. The density of proteolytic bacteria at locations $\mathrm{A}, \mathrm{B}$, and $\mathrm{C}$ were $3.96 \times$
$10^{3} \mathrm{CFU} \mathrm{g}^{-1}, 4.13 \times 10^{3} \mathrm{CFU} \mathrm{g}^{-1}$, and $3.93 \times 10^{3} \mathrm{CFU} \mathrm{g}^{-1}$ respectively. The $\mathrm{pH}$ of samples from locations $\mathrm{A}, \mathrm{B}$, and $\mathrm{C}$ were $6.23,6.27$, and 6.5 (Table 1). C-organic and organic content, water content, and temperature of the sampling locations were presented in Table 1. A total of 20 proteolytic bacteria isolates and 22 chitinolytic bacteria isolates were successfully isolated from the samples. All isolates produce clear zones around their colony during the growth. Isolates were differentiated based on morphological characters of the colony.

\section{Enzymatic activities \\ Protease activity}

There were three isolates (AP9, AP5, and BP14) that had high protease activity with protease activity of $25.56 \pm$ $2.4 ; 24.93 \pm 0.59 ; 21.36 \pm 2$ Units $\mathrm{mL}-1$ enzyme per minute, respectively $(\mathrm{p}<0.05)$ (Figure 1). Therefore, isolates of AP9, AP5, and BP14 were selected for further evaluation of chitinolytic activity.

\section{Chitinase activity}

A total of 22 chitinolytic bacterial isolates was assayed for its chitinase enzyme activity according to the completely randomized design. Three selected proteolytic bacteria (isolates of AP9, AP5, and BP14) were assayed for chitinase activity. The N-acetyl-D-glucosamine was measured based on the N-acetyl-D-glucosamine standard curve. As a result, BP14 isolate showed the highest chitinase activity of $0.796 \pm 0.13$ Units $\mathrm{mL}-1$ enzyme per hour. It was relatively similar to a chitinolytic isolate of CK20 with $0.718 \pm 0.15$ Units mL-1 enzyme per hour ( $\mathrm{p}<$ 0.05 ) (Figure 2). Based on the enzymatic activity, isolate of AP9, AP5, BP14, and CK20 were selected for hemolysis activity assay and identified based on $16 \mathrm{~S}$ rDNA sequences.

\section{Hemolytic activity}

Hemolysis activity test of four potential isolates (BP14, CK20, AP9, and AP5) resulted in two non-pathogenic isolates, namely AP5 and CK20 isolates with an indication of no reaction on the blood agar media after 24 hours incubation. BP14 isolate showed alpha hemolysis activity, which was indicated by changes in green color on blood agar media while AP9 isolate had beta hemolysis activity, which was characterized by color changes in red blood cells becomes clear or lysis.

Table. 1. The population density of chitinolytic and proteolytic bacteria and the physicochemical parameters of sampling locations.

\begin{tabular}{lccc}
\hline \multirow{2}{*}{ Parameters } & \multicolumn{3}{c}{ Sampling location } \\
\cline { 2 - 4 } & Rembang A & Pati & Rembang B \\
\hline Chitinolytic bacteria (x104 CFU g-1)* & $4.96 \pm 0.15 \mathrm{a}$ & $11.13 \pm 0.60 \mathrm{~b}$ & $4.63 \pm 1.2 \mathrm{a}$ \\
Proteolytic bacteria (x103 CFU g-1)* & $3.63 \pm 0.81 \mathrm{a}$ & $4.40 \pm 2.26 \mathrm{a}$ & $3.26 \pm 0.72 \mathrm{a}$ \\
C-Organic (\%) & $3.10 \pm 0.26 \mathrm{a}$ & $4.26 \pm 0.32 \mathrm{~b}$ & $2.47 \pm 0.44 \mathrm{a}$ \\
Organic matter $(\%)$ & $5.35 \pm 0.47 \mathrm{a}$ & $7.4 \pm 0.52 \mathrm{~b}$ & $4.23 \pm 0.76 \mathrm{a}$ \\
Water content $(\%)$ & $8.43 \pm 0.35 \mathrm{~b}$ & $21.92 \pm 0.73 \mathrm{c}$ & $5.26 \pm 0.15 \mathrm{a}$ \\
pH & $6.23 \pm 0.05 \mathrm{a}$ & $6.27 \pm 0.23 \mathrm{a}$ & $6.5 \pm 0.1 \mathrm{a}$ \\
Temperature $\left({ }^{\circ} \mathrm{C}\right)$ & $30.96 \pm 1.81 \mathrm{a}$ & $32.13 \pm 0.23 \mathrm{a}$ & $32.53 \pm 0.73 \mathrm{a}$ \\
\hline
\end{tabular}




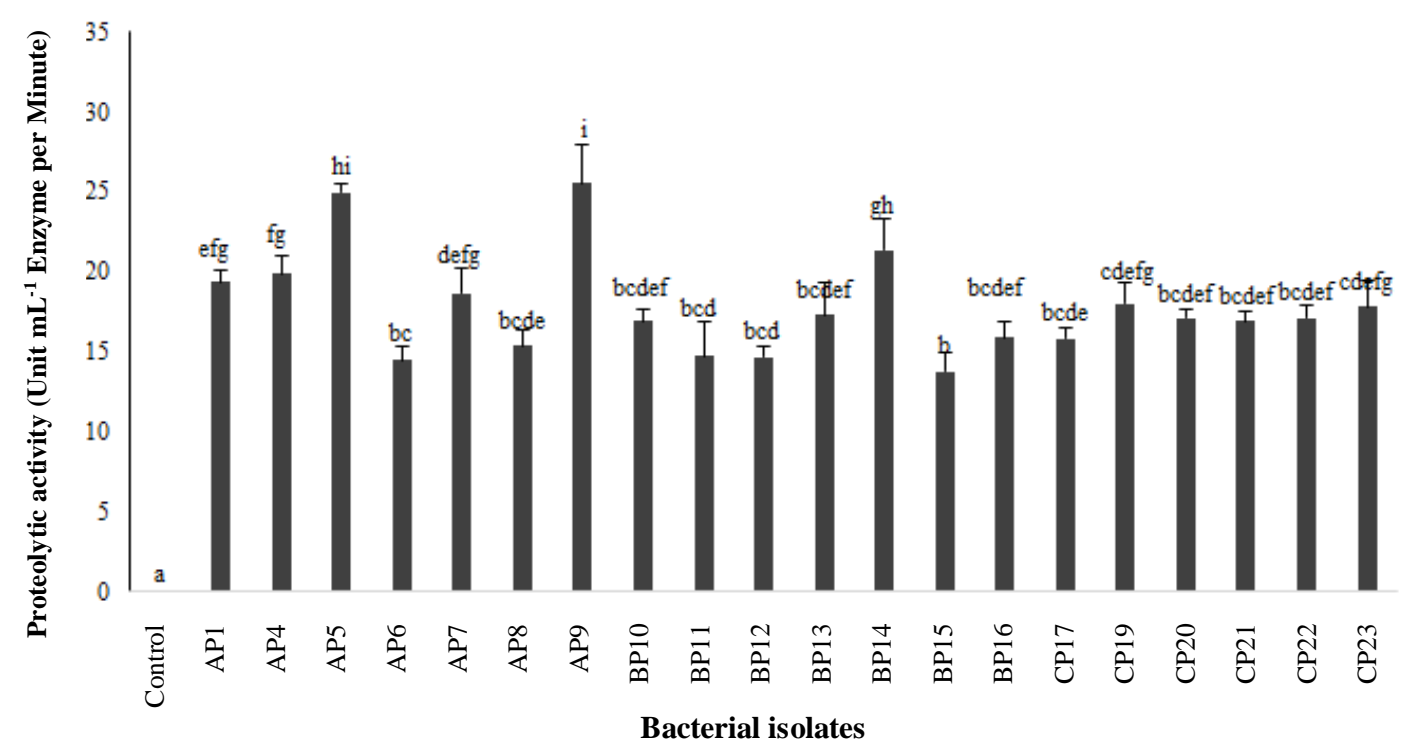

Figure 1. Protease activity of proteolytic bacteria. Data were presented as mean \pm standard deviation with significant differences $p<0.05$

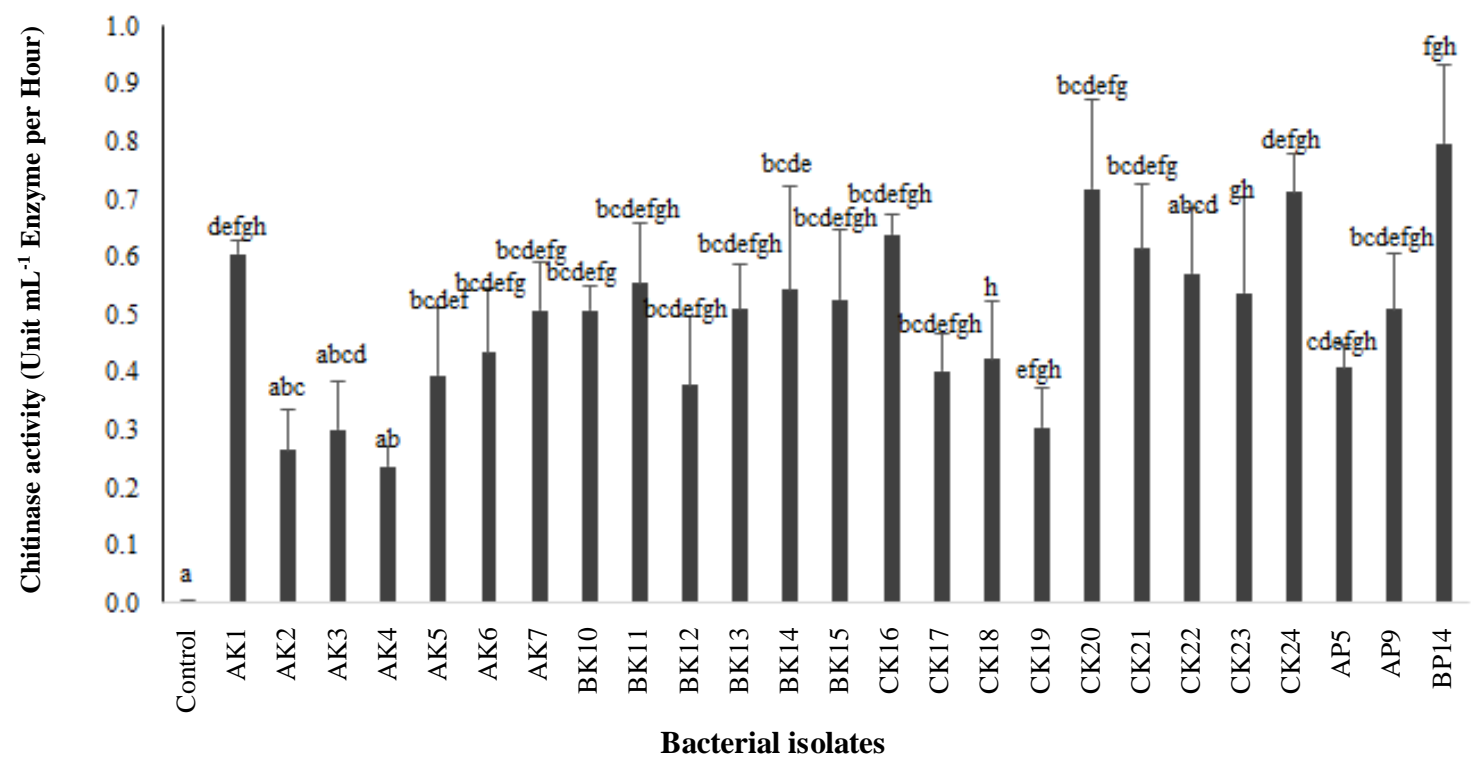

Figure 2. Chitinase activity of the bacteria isolates. Data were presented as mean \pm standard deviation with significant differences $p<0.05$

\section{Identification of Selected species based on $16 \mathrm{~S}$ rDNA sequences similarity}

Morphological characters of selected bacteria isolates showed various sizes and shapes. All selected isolates were identified as Gram-positive rod bacteria (Table 2). Gram staining of 4 selected isolates was presented in Figure 3. The 16S rDNA of each selected isolate was successfully amplified with a size of about 1500 bp (Figure 4). These isolates were identified based on $16 \mathrm{~S}$ rDNA sequences as the genus of Bacillus. The isolate of AP9 was identified as Bacillus subtilis, isolate of AP5, and CK20 was identified as Bacillus licheniformis, and isolate of BP14 was identified as Bacillus cereus (Figure 5).

\section{Discussion}

Proteolytic bacteria produce protease to hydrolyze proteins in crab shells into amino acids, which are used as a source of nitrogen for bacterial growth, while chitinolytic bacteria produce chitinase to hydrolyze chitin into reduced sugars as a source of carbon and energy for bacterial growth. The abundance of proteolytic and chitinolytic bacteria in Pati District was higher than in Rembang A, and B District was $11.13 \pm 0.60 \times 103 \mathrm{CFU} \mathrm{g}^{-1}$ and $4.40 \pm 2.26$ $\times 104 \mathrm{CFU} \mathrm{g}^{-1}$ respectively. C-organic content, organic matter, and water content in Pati Regency were higher than two locations in Rembang Regency thus supporting the growth of bacteria. As a consequence, proteolytic and 
chitinolytic bacteria were significantly higher in Pati Regency. However, $\mathrm{pH}$ and temperature did not significantly influence the abundance of proteolytic and chitinolytic bacteria (Table 1). Physicochemical properties in bacterial habitat affect bacterial growth. Physicochemical properties that most influence bacterial growth was temperature, $\mathrm{pH}$, and $\mathrm{C} / \mathrm{N}$ source (Faramarzi et al. 2009). Physicochemical properties also influence the production of bacterial enzymes, including protease and chitinase. Crab shells contain $18.14 \%$ protein, $0.25 \%$ fat, $29.78 \%$ ash, $8.68 \%$ water, and $43.15 \%$ carbohydrates (Kraisangsri et al. 2018), 30-50\%, CaCO3 and astaxanthin (Susanto and Sopiah 2003). Chitin is the most significant amount in crab shells and as the main carbon source at the sampling site for bacterial growth. Therefore, chitinolytic bacteria were more abundant than proteolytic bacteria.

Proteolytic and chitinolytic bacteria in sampling sites can influence the degradation process of crab shells. The results of this study showed that there were 2 isolates with high proteolytic activity (AP9 and AP5) and two isolates with high chitinolytic activity (BP14 and CK20). Therefore, these isolates may have the potential to degrade crab shell waste. The activity of an enzyme is influenced by several factors, such as $\mathrm{pH}$, substrate and enzyme concentrations, temperature and the presence of an activator or inhibitor (Nelson and Cox 2005).

The results of the hemolysis test of four potential isolates (BP14, CK20, AP9, and AP5) showed that there was two bacterial isolates indication were pathogenic (BP14 and AP9), and two isolates were nonpathogenic. Nonpathogenic bacteria can be used directly in the industrial application, while pathogenic bacteria should be processed first to isolate the enzyme.

All selected isolates in this study were identified as the genus of Bacillus. As reported in the previous study, Bacillus species are the primary bacteria groups that

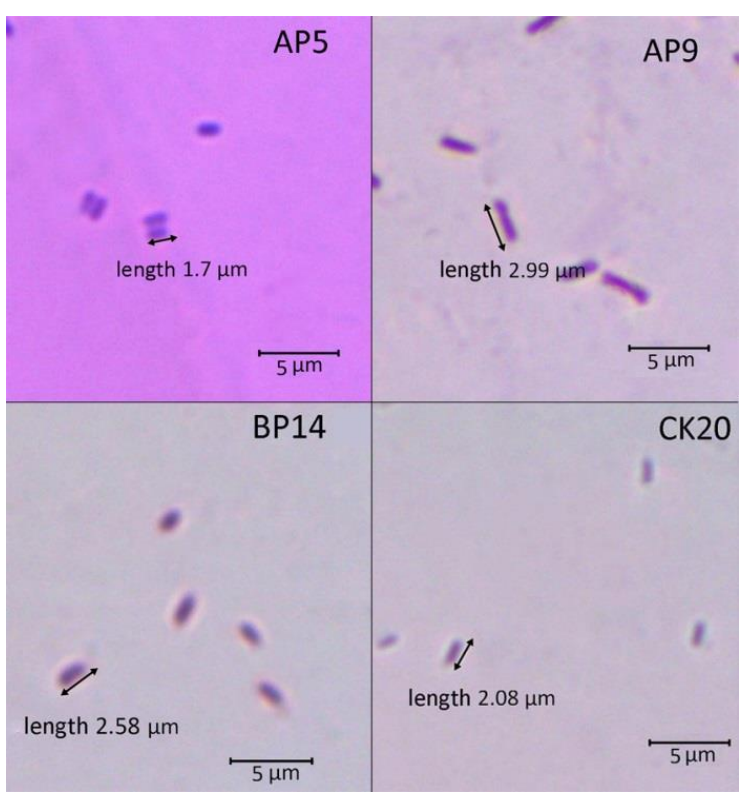

Figure 3. The shape of the selected bacterial cell. AP5, and AP9: proteolytic bacteria, BP14, and CK20: chitinolytic bacteria. produce extracellular protease enzymes (Degering et al. 2010; Pant et al. 2015). The extracellular protease enzyme is widely used in industrial applications for pharmaceuticals, leather, detergents, food, and agriculture (Pant et al. 2015). The closely related species of Bacillus subtilis and Bacillus licheniformis are frequently used as the extracellular protease-producers on an industrial scale, they are also endotoxin-free and generally regarded as safe (GRAS) status (Degering et al. 2010). Bacillus cereus GB23.4 have potency as biodegradation agents and biosurfactants, the strains had degraded single proteins and red blood cell simultaneously (Sutoyo et al. 2019).

Table. 2. Morphological characters of chitinolytic and proteolytic bacteria

\begin{tabular}{|c|c|c|c|c|c|c|}
\hline & \multirow{2}{*}{\multicolumn{2}{|c|}{ Character }} & \multicolumn{4}{|c|}{ Isolates } \\
\hline & & & \multirow{2}{*}{$\frac{\text { AP5 }}{+}$} & \multirow{2}{*}{$\frac{\text { AP9 }}{+}$} & \multirow{2}{*}{$\frac{\text { BP14 }}{-}$} & \multirow{2}{*}{$\frac{\text { CK20 }}{+}$} \\
\hline \multirow{10}{*}{ 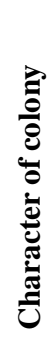 } & Shapes & Irregular & & & & \\
\hline & & Filamentous & + & - & - & - \\
\hline & & Circular & - & - & + & - \\
\hline & & Nucleated & - & - & - & + \\
\hline & Pigments & White milk & + & + & + & - \\
\hline & & Clear & - & - & - & + \\
\hline & Margins & Entire & + & + & + & + \\
\hline & Elevations & Convex & + & - & + & - \\
\hline & & Wrinkled & + & - & - & - \\
\hline & & Flat & - & + & - & + \\
\hline \multirow{6}{*}{ 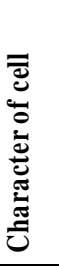 } & Size $(\mathrm{cm})$ & - & 1.41 & 3.92 & 0.22 & 0.77 \\
\hline & Gram & Positive & + & + & + & + \\
\hline & & Negative & - & - & - & - \\
\hline & Shape & Bacillus & + & + & + & + \\
\hline & & Coccus & - & - & - & - \\
\hline & Size $(\mu \mathrm{m})$ & - & 1.7 & 2.99 & 2.58 & 2.08 \\
\hline
\end{tabular}

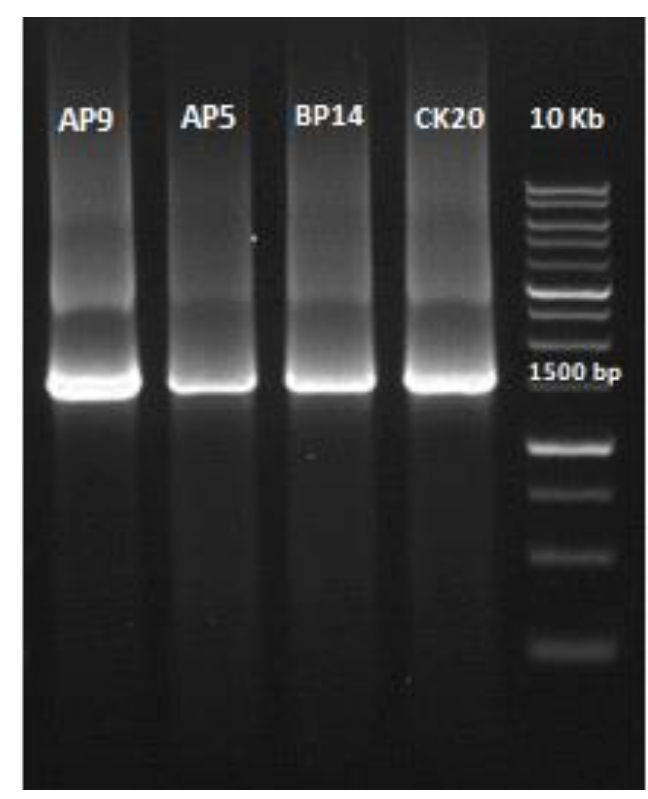

Figure 4. Agarose gel electrophoresis of selected bacterial isolates after 16S rDNA amplification 


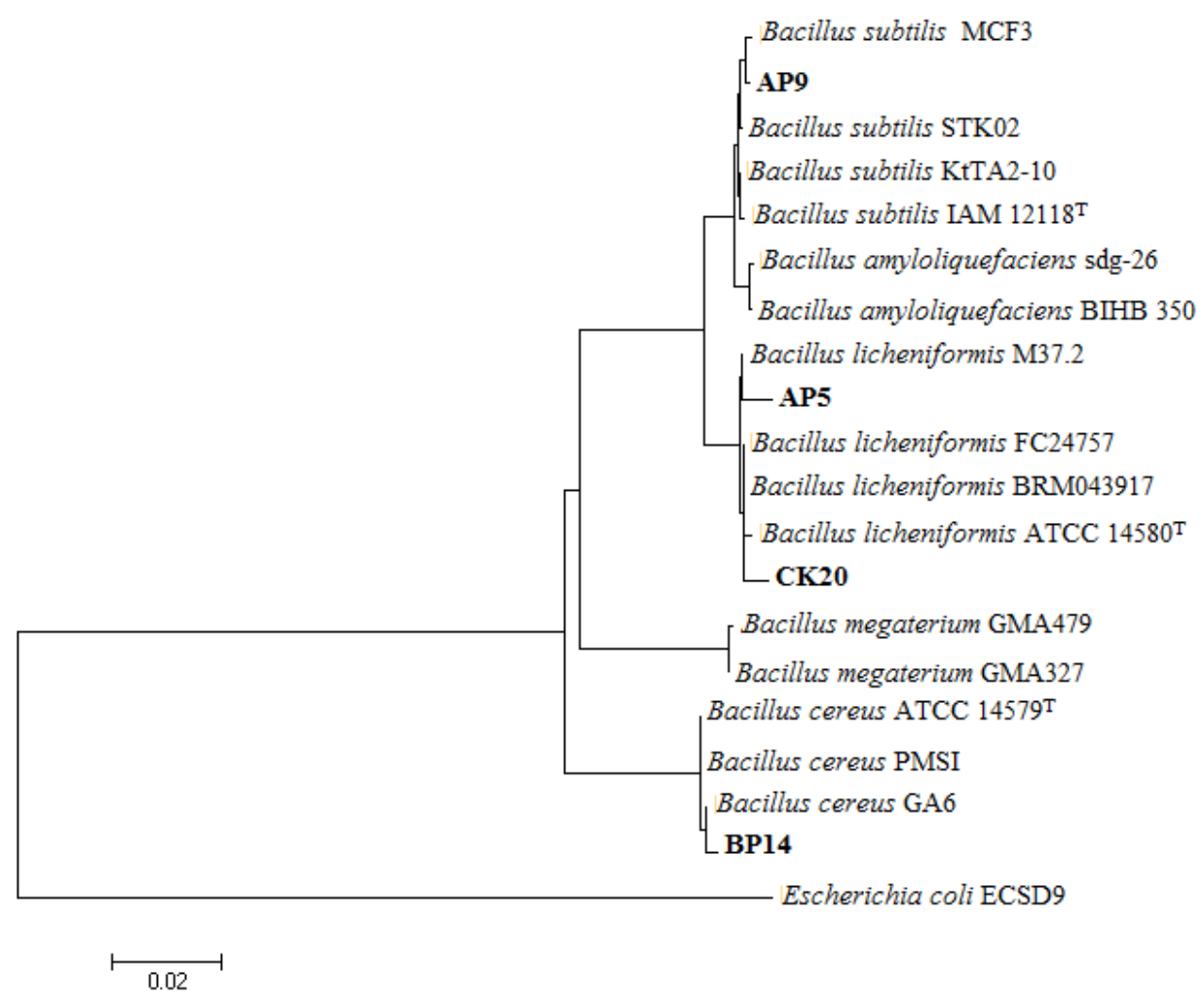

Figure. 5. Phylogeny tree of Bacillus sp. based on the 16S rDNA sequences with the Neighbor-Joining algorithm and Tamura-Nei model

In this study, Bacillus cereus BP14 and Bacillus subtilis AP9 can degrade crab shell, blood agar as well as hydrolyzed skim milk agar and colloidal chitin agar. Therefore, clear zone on medium blood agar indicate was surfactant and low toxicity, but it's necessary to do further pathogen testing for safety. The level of chitin degradation from crab shells waste is also influenced by chitinase activity, environmental factors, metabolism of native microorganisms in using carbon as an energy source, protein synthesis, and the release of cell metabolic products (Bailly and Ollies 1986; Setia and Suharjono 2015). A study by Karadag et al. (2009) showed that B. subtilis produces protease optimally at $\mathrm{pH} 7.4$ with galactose and peptone as the primary carbon and nitrogen source, while the highest enzyme activity obtained at $\mathrm{pH} 8$ using casein as a substrate. In this study, the conditions for enzymatic activity assays are neutral $\mathrm{pH}$ at $30^{\circ} \mathrm{C}$. The optimization of $\mathrm{pH}$, temperature, carbon, and nitrogen sources have not been done yet.

The enzyme activity of proteolytic bacteria in this study was lower than protease activity by Serratia marcescens FS-3 in a different genus 60.7 Units $\mathrm{mL}^{-1}$ )at $\mathrm{pH} \mathrm{7,} 30{ }^{\circ} \mathrm{C}$ (Jo et al. 2008). Rachanamol et al. (2018) reported that protease production of Bacillus subtilis VCDA was 54 Units $\mathrm{mL}^{-1}$ after 48 hours incubation, at $30^{\circ} \mathrm{C}$, and $\mathrm{pH} 7$. Other strain of Bacillus subtilis can produce 243.28 Units protease $\mathrm{mL}^{-1}$ per minute after $36 \mathrm{~h}$ incubation (Pant et al. 2015). Thus, it is necessary to optimize conditions for protease production using $B$. subtilis and $B$. licheniformis with maximum enzymatic activity. However, this is not the first isolate of $B$. subtilis and $B$. licheniformis that produce high extracellular protease activity. Most commercial proteases are produced by the genus of Bacillus. Neutral protease in this study is active in the $\mathrm{pH}$ range of 5 to 8 and relatively low thermo-tolerance while alkaline protease is active in pH range up to $\mathrm{pH} 10$ and relatively high thermotolerance (Rao et al. 1998).

Both of B. subtilis and B. licheniformis is not only able to produce proteases but also have the ability to produce chitinases (Gomaa 2012; Senol et al. 2014). However, in this study, the bacteria which have high chitinase activity are Bacillus cereus and Bacillus licheniformis. Chitinase enzyme used to hydrolyze chitin that derived primarily from insects and crustaceans exoskeletons (Hsieh et al. 2010). Similar to the conditions for protease production, the requirements for chitinase production in this study have not been optimized yet. However, the chitinase activity in this study was relatively higher than in other studies. A study by Lamine et al. (2012) showed that Serratia marcescens DSM $30121545^{\mathrm{T}}$ had the highest chitinase activity of 0.556 Units $\mathrm{mL}^{-1}$ on a medium containing $1 \%$ colloidal chitin, at $30^{\circ} \mathrm{C}$, and $\mathrm{pH}$ 6. Saleem et al. (2014) reported that Bacillus thuringiensis CMBL-Bt4 had the highest chitinase activity compared to 12 other Bacillus thuringiensis at 0.23 Units $\mathrm{mL}^{-1}$ after 4 days incubation at $37^{\circ} \mathrm{C}, \mathrm{pH}$ 7. The optimum temperature and $\mathrm{pH}$ for the 
chitinase activity of ChilO8 (chitinase enzyme produced by Bacillus cereus) was $60^{\circ} \mathrm{C}$ and $\mathrm{pH} 6.5$ (Hammami et al. 2013). A satisfying result in this study was that Bacillus cereus BP14 could produce protease and chitinase enzymes with good activity. Besides, chitinases produced by Bacillus sp. have the potency as antifungal activity such as B. subtilis CH426 and B. cereus J1 (Zarei et al. 2011; Yang et al. 2009; Wang and Hwang 2001) and have the potency as bio-control agents against insects (eco-friendly bioinsecticide) (Kuzu et al. 2012). And chitinases produced by Bacillus cereus BP14 could be assay to produce antifungal activity.

Crab shell waste can be used as a good source for the isolation of proteolytic and chitinolytic bacteria, which naturally can utilize chitin-protein fibers as a nutrition source. Selected strains can be used to facilitate the degradation of crab shell waste or used for alkaline protease and chitinase production on an industrial scale to increase the economic value of crab shell waste.

In conclusion, the indigenous bacteria isolated from crab shell waste from Pati and Rembang regency, which have the highest proteolytic enzyme activity were Bacillus subtilis AP9 and Bacillus licheniformis AP5, while the highest chitinolytic enzyme activity was Bacillus licheniformis CK20. Bacillus cereus BP14 was bacteria that possess high proteolytic and chitinolytic activities, but it was indicated pathogenic bacteria based on hemolysis assay. Optimization of $\mathrm{pH}$, temperature, and incubation time to obtain the highest enzymatic activity of selected isolates still need to be studied.

\section{REFERENCES}

Angmo K, Kumari A, Savitri, Bhalla TC. 2016. Probiotic characterization of lactic acid bacteria isolated from fermented foods and beverage of Ladakh. LWT-Food Sci Technol 66: 428-435. DOI: 10.1016/j.lwt.2015.10.057.

Azuma K, Ifuku S, Osaki T, Okamoto Y, Minami S. 2014. Preparation and biomedical applications of chitin and chitosan nanofibers. J Biomed Nanotechnol 10: 2891-2920.

Bailly JE, Ollis DF. 1986. Biochemical Engineering Fundamentals. McGraw-Hill, New York.

Cupp-Enyard C. 2008. Sigma's non-specific protease activity assay-casein as a substrate. JoVE 19: 899.

Degering C, Eggert T, Puls M, Bongaerts J, Evers S, Maurer KH, Jaeger KE. 2010. Optimization of Protease Secretion in Bacillus subtilis and Bacillus licheniformis by screening of homologous and heterologous signal peptides. Appl Environ Microbiol 76: 6370-6376.

Elieh-Ali-Komi D, Hamblin MR. 2016. Chitin and chitosan: production and application of versatile biomedical nanomaterials. Intl J Adv Res (Indore) 4: 411-427.

Faramarzi M, Fazeli M, Yazdi MT, Adrangi S, Al Ahmadi KJ, Tasharrofi N, Mohseni FA. 2009. Optimization of cultural conditions for production of chitinase by a soil isolate of Massilia timonae. Biotechnology 8: 93-99.

Fulzele R, DeSa E, Yadav A, Shouche Y, Bhadekar R. 2011. Characterization of novel extracellular protease produced by marine bacterial isolate from the Indian ocean. Braz J Microbiol 42: 13641373.

Gadgey K, Bahekar A. 2017. Investigation of mechanical properties of crab shell: a review. Intl J Latest Trends Eng Technol 1: 268-281.

Gomaa EZ. 2012. Chitinase production by Bacillus thuringiensis and Bacillus licheniformis: Their potential in antifungal biocontrol. J Microbiol 50: 103-111.
Gortari MC, Hours RA. 2013. Biotechnological processes for chitin recovery out of crustacean waste: a mini-review. Electron $\mathrm{J}$ Biotechnol 16: 14. DOI: 10.2225/vol16-issue3-fulltext-10

Hajji S, Younes I, Ghorbel-Bellaaj O, Hajji R, Rinaudo M, Nasri M, Jellouli K. 2014. Structural differences between chitin and chitosan extracted from three different marine sources. Int $\mathrm{J}$ Biol Macromol 65: 298-306.

Hammami I, Siala R, Jridi M, Ktari N, Nasri M, Triki MA. 2013. Partial Purification and characterization of Chiio8, A novel antifungal chitinase produced by Bacillus cereus IO8. J Appl Microbiol 115: 358-366.

Hsieh YC, Wu YJ, Chiang TY, Kuo CY, Shrestha KL, Chao CF, Chen CJ. 2010. Crystal structures of Bacillus cereus NCTU2 chitinase complexes with chitooligomers reveal novel substrate binding for catalysis. J Biol Chem 285: 31603-31615.

Jayakumar R, Prabaharan M, Sudheesh KPT, Nair SV, Tamura H. 2011. Biomaterials based on chitin and chitosan in wound dressing applications. Biotechnol Adv 29: 322-337.

Jo GH, Jung WJ, Kuk JH, Oh KT, Kim YJ, Park RD. 2008. Screening of protease-producing Serratia marcescens FS-3 and its application to deproteinization of crab shell waste for chitin extraction. Carbohydrate Polymers 74: 504-508.

Karadag D, Mäkinen AE, Efimova E, Puhakka JA. 2009. Thermophilic biohydrogen production by an anaerobic heat treated-hot spring culture. Bioresour Technol 100: 5790-5795.

Kraisangsri J, Nalinanon S, Riebroy S, Yarnpakdee S, Ganesan P. 2018. Physicochemical characteristics of glucosamine from blue swimming crab (Portunus pelagicus) shell prepared by acid hydrolysis. Walailak J Sci Tech 15: 869-877.

Kumari S, Rath PK. 2012. Extraction and characterization of chitin and chitosan from Labeo Rohit Fish scales. Proc Mater Sci 6: 482-489.

Kuzu SB, Güvenmez HK, Denizci AA. 2012. Production of a Thermostable and Alkaline Chitinase by Bacillus thuringiensis subsp. kurstaki Strain HBK-51. Biotechnol Res Intl 2012: 135498. DOI: $10.1155 / 2012 / 135498$.

Lamine BM, Lamine BM, Bouziane A. 2012. Optimization of the chitinase production by Serratia marcescens DSM 30121T and biological control of locusts. J Biotechnol Biomater 2: 13-138. DOI: 10.4172/2155-952X.1000133.

Lopes C, Antelo LT, Franco-Uría A, Alonso AA, Pérez-Martín R. 2017. Chitin production from crustacean biomass: sustainability assessment of chemical and enzymatic processes. J Clean Prod. DOI: 10.1016/j.jclepro.2017.01.082.

Mageswari A, Subramanian P, Chandrasekaran S, Karthikeyan S, Gothandam KM. 2017. Systematic functional analysis and application of a cold-active serine protease from a novel Chryseobacterium sp. Food Chem 217: 18-27.

Mulyawati AI, Jatmiko YD, Mustafa I, Ardyati T, Suharjono. 2019. Diversity of lactic acid bacteria isolated from fermented mare's milk products based on PCR-RFLP analysis. IOP Conf. Ser.: Earth Environ. Sci. 230: 012104. DOI:10.1088/1755-1315/230/1/012104

Nelson DL, Cox MM. 2005. Lehninger: Principles of Biochemistry. WH Freeman and Company, New York.

Nouri M, Khodaiyan F, Razavi SH, Mousavi M. 2016. Improvement of chitosan production from Persian gulf shrimp waste by response surface methodology. Food Hydrocolloid 59: 50-58.

Ordó nez-Del Pazo T, Antelo LT, Franco-Uría A, Pérez-Martín RI, Sotelo CG, Alonso AA. 2014. Fish discards management in selected Spanish and Portuguese métiers: identification and potential valorisation. Trends Food Sci Technol 36: 29-43.

Pant G, Prakash A, Pavani JVP, Bera S, Deviram GVNS, Kumar A, Prasuna RG. 2015. Production, optimization and partial purification of protease from Bacillus subtilis. J Taibah Univ Sci 9: 50-55.

Rachanamol RS, Lipton AP, Thankamani V, Sarika AR, Selvin J. 2017. Production of protease showing antibacterial activity by Bacillus subtilis VCDA associated with tropical marine sponge Callyspongia diffusa. J Microbial Biochemical Technol 9: 6. DOI: 10.4172/19485948.1000376

Rao MB, Tanksale AM, Ghatge MS, Deshpande VV. 1998. Molecular and biotechnological aspects of microbial proteases. Microbiol Mol Biol Rev 62: 597-635.

Raut S, Sen SK, Kabir NA, Satpathy S, Raut S. 2012. Isolation and characterization of protease producing bacteria from upper respiratory tract of wild chicken. Bioinformation 8: 326-330. 
Riniwati H, Harahab N, Carla TY. 2017. Analysis of Indonesia crab export competitiveness in international market. Intl Rev Manag Mark 7: 23-27.

Rustad T, Storro I, Slizyte R. 2011. Possibilities for the utilization of marine by-products. Intl J Food Sci Technol 46: 2001-2014.

Saima, Kuddus M, Roohi, Ahmad IZ. 2013. Isolation of novel chitinolytic bacteria and production optimization of extracellular chitinase. J Genet Eng Biotechnol 11: 39-46.

Saleem F, Younas A, Bashir R, Naz S, Munir N, Shakoori AR. 2014. Molecular cloning and characterization of exochitinase a gene of indigenous Bacillus thuringiensis isolates. Pak J Zool 46: 1491-1501.

Sanmartin E, Arboleya JC, Iloro I, Escuredo K, Elortza F, Moreno FJ. 2012. Proteomic analysis of processing by-products from canned and fresh tuna: identification of potentially functional food proteins. Food Chem 134: 1211-1219.

Senol M, Nadaroglu H, Dikbas N, Kotan R. 2014. Purification of chitinase enzymes from Bacillus subtilis bacteria TV-125, investigation of kinetic properties and antifungal activity against Fusarium culmorum. Ann Clin Microbiol Antimicrob 13: 35. DOI: 10.1186/s12941-0140035-3

Senphan T, Benjakul S, Kishimura H. 2014. Characteristics and antioxidative activity of carotenoproteins from shells of Pacific White Shrimp extracted using hepatopancreas proteases. Food Biosci 5: 54 63.
Setia IN, Suharjono. 2015. Chitinolytic assay and identification of bacteria isolated from shrimp waste based on $16 \mathrm{~S}$ rDNA sequences. Adv Microbiol 5: 541-548. DOI: 10.4236/aim.2015.57056.

Susanto JP, Sopiah N. 2003. Effect of metals and concentration on growth and activity of proteolytic bacteria in the deproteination process of small skin. J Environ Technol 4: 40-46.

Sutoyo, Subandi, Ardyati T, Suharjono. 2019. Isolation and identification of keratinolytic bacteria from Jember, Indonesia as a biodegradation agent of chicken feather wastes. Asian J Agric Biol 7(4): 1-1.

Tennalli G, Udapudi B, Naik P. 2012. Isolation of proteolytic bacteria and characterization of their proteolytic activity. Intl $\mathbf{J}$ Adv Eng Sci Technol 2: 185-192.

Tolaimate A, Desbrieres J, Rhazia M, Alagui A. 2003. Contribution to the preparation of chitins and chitosans with controlled physicochemical properties. Polymer 44: 7939-7952.

Wang SL, Hwang JR. 2001. Microbial reclamation of shellfish wastes for the production of chitinases. Enzyme Microb Technol 28: 376-382.

Yang CY, Ho YC, Pang JC, Huang SS, Tschen JSM. 2009. Cloning and expression of an antifungal chitinase gene of novel Bacillus subtilis isolated from Taiwan potato field. Bioresour Technol 100: 14541458 .

Zarei M, Aminzadeh S, Zolgharnein H, Safahieh A, Daliri M, Noghabi KA, Motallebi A. 2011. Characterization of a Chitinase with Antifungal Activity from a Native Serratia marcescens B4A. Braz J Microbiol 42: 1017-1029. 